\title{
The Top Management Team, Reflexivity, Knowledge Sharing and New Product Performance: A Study of the Irish Software Industry
}

\author{
Sarah MacCurtain, Patrick C. Flood, \\ Nagarajan Ramamoorthy, Michael A. West and \\ Jeremy F. Dawson
}

In the present study, we develop a model to predict new product performance incorporating the literature on top management team (TMT) composition, trustworthiness, knowledge sharing and task reflexivity in organizations. We hypothesize that diversity and trustworthiness in the TMT should influence knowledge sharing and reflexivity and reflexivity and knowledge sharing would be positively associated with new product performance. We test the model using data collected from 39 indigenous software firms in Ireland. Results indicate that age diversity was positively related to knowledge sharing ability while educational level, tenure and functional diversity of the TMT did not have any direct effect on reflexivity or knowledge sharing ability or motivation. However, educational level of TMT, tenure and age diversity had indirect effects on reflexivity and knowledge sharing through the intervening variable of TMT trustworthiness. Further, knowledge sharing and task reflexivity had direct effects on market new product performance. Implications for research and practice are discussed.

\section{Introduction}

$\mathrm{T}$ The literature on innovation suggests that organizations can create and sustain a competitive advantage by being innovative (Baldwin, 1995; Schulz, 2001; Tidd, Bessant \& Pavitt, 2005). Studies have shown that product innovations result in growth, higher profitability and market share (Tidd, 2001; Prajogo \& Ahmed, 2007) and process innovations such as re-engineering result in productivity growth (Black \& Lynch, 2004). Further, studies have shown that capacity to innovate has been related to top team diversity, participative leadership, trust, reflexivity (Kimberly, 1981; Song \& Dyer, 1998; West, 2000), knowledge sharing (West \& Anderson, 1996; Nonaka, 1999; Smith, Collins \& Clark, 2005), top management team (TMT) composition (Bantel \& Jackson, 1989), values of the TMT (Hage \&
Dewar, 1973) and TMT support for innovation (West \& Anderson, 1996). However, with the exception of the TMT composition/diversity literature, little research has been conducted to understand the role of TMT social and psychological processes in influencing organizational innovation and the subsequent performance of new products in the market.

One body of literature focuses on TMT composition as influencing organizational innovation. Since these managers make decisions consistent with their cognitive base (a function of education, functional background and experience) and their values (Smith et al., 1994), it is often argued that TMT composition may directly affect organizational outcomes such as innovation (Bantel \& Jackson, 1989; O'Reilly \& Flatt, 1989). The literature on TMT diversity suggests that certain demographic characteristics (e.g., education) affect group processes positively while others (e.g., age diversity) 
have a negative effect. Thus, this stream of research emphasizes the 'aggregated external characteristics of the team such as heterogeneity, tenure and size' or what the team is (Smith et al., 1994) as influencing innovation.

The general innovation literature suggests that team processes and behaviours such as reflexivity, task conflict and knowledge sharing are also important predictors of innovation (De Dreu, 2002, 2006; Tjosvold, Tang \& West, 2004). Unlike the TMT composition and diversity literature, group processes refer to what the team does (e.g., Marks, Mathieu \& Zaccaro, 2001). We focus on two important team processes - task reflexivity and knowledge sharing. Task reflexivity is a relatively new but important addition to the team process literature. While the study of reflexivity in organizational theory is still relatively rare, there are some important studies within this discipline indicating that it has a beneficial effect upon team innovation, enhancing creativity and improving task outcomes (Anderson, Hardy \& West, 1990; West, 1996; West \& Anderson, 1996). Although the majority of the research on reflexivity and innovation explores innovation in lower level teams (West, Borrill \& Unsworth, 1998; West, 2000), it is plausible to suggest that reflexivity within the top team may also have implications for the firm in terms of innovations through reflexive behaviours such as monitoring of external and internal environment, critical problem solving and adaptation (West et al., 2004; Hoegl \& Parboteeah, 2006).

We also focus on knowledge sharing within the top management team. Writers on innovation argue that knowledge is central to the innovation process - the ability and willingness to share and combine knowledge is core to new product development (NPD) and innovation - particularly the sharing of new, diverse knowledge (Nonaka \& Takeuchi, 1995; Mascitelli, 2000; Spencer, 2003; Smith, Collins \& Clark, 2005).

While there is a wealth of literature on the TMT, little is known about the effects of TMT composition on the group process variables of task reflexivity and knowledge sharing and how such processes may influence organizational innovation. Certain demographic characteristics, such as education have been shown to have positive effects on group processes while other demographic characteristics such as age diversity exhibit negative effects. The levels of trust within the top management team will also influence a team's willingness to share knowledge and reflect upon past decisions. Thus, an interdisciplinary approach based on integrating TMT composition literature based on sociological theories, dynamics of group processes based on psychological theories and the literature on innovation should provide us with a richer understanding of the dynamics of innovation in organizational settings.

Adopting an interdisciplinary approach, we propose that TMT composition will be related to task reflexivity and knowledge sharing. Further, trustworthiness among TMT members will be associated with task reflexivity and knowledge sharing. Finally, we propose a relationship between the levels of task reflexivity and knowledge sharing and new product performance. Thus, the goal of the present study is to integrate these diverse literatures to develop and test a model of new product performance using data collected from thirty-nine software firms in Ireland thereby providing an interdisciplinary approach to new product performance.

This paper is organized into four sections. In the next section, we develop our hypothesized model using the literature on top management teams and knowledge sharing. We then present the methodology used to test the hypothesized model followed by the results of our study. Finally, we conclude with implications for research and practice.

\section{Review of the Literature and Model Development}

\section{Overview of the Model}

Figure 1 presents the overview of the model that the present study proposes. In our model, we hypothesize that TMT trustworthiness, educational level (knowledge stock), and diversity will affect the two process variables knowledge sharing and reflexivity. We further hypothesize that the two process variables will influence new product performance of the firm. We now review the literature to provide support for our hypothesized model.

\section{The Nature of Innovation and New Product Performance}

Kimberly and Evanisko (1981) describe innovation as occurring in three ways: as process, as discrete items including products and services and as an attribute of the organization (i.e., an innovative organization). These three innovation types are conceptually compatible and inextricably linked as the innovation process culminates with innovation outcomes and firms that cycle through the process relatively frequently are described as 'innovative' (Bantel \& Jackson, 1989, p. 108). The ultimate test of any innovation - new products or 


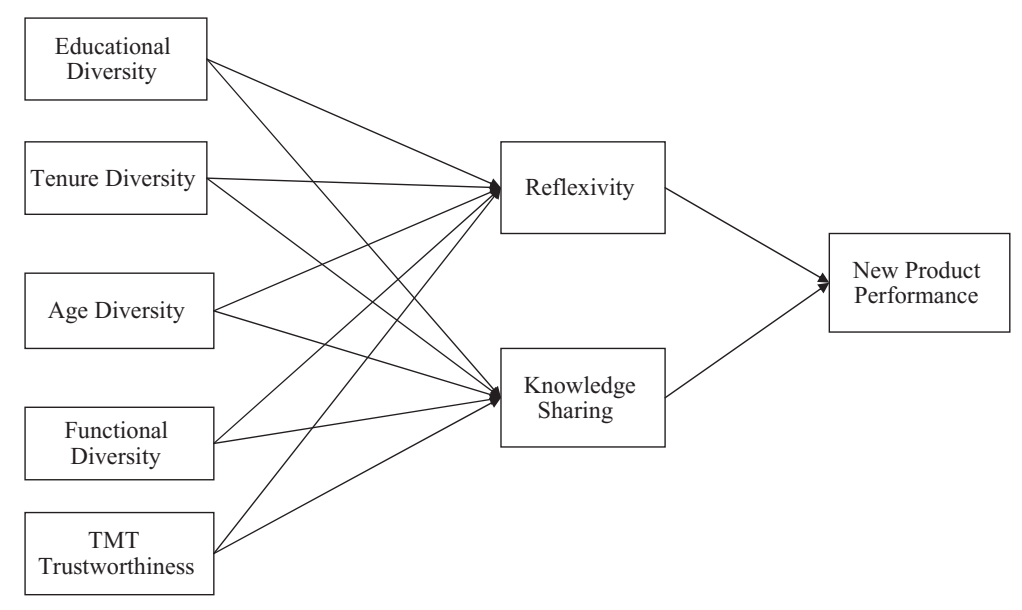

Figure 1. Top Management Team (TMT) Knowledge Sharing and New Product Performance: The Hypothesized Model

services - is the marketplace. Innovative firms gain and sustain their competitive advantage through the development of new products which are appealing to existing and new customers and how such products perform in the market. Such new products are critical because of their ability to become a means of market share gain and revenue growth (Bergstein \& Estelami, 2002). Lyon and Ferrier (2002) focus on 'product-market' innovation, a measure of innovation that incorporates both product design and market-related activities. Consistent with the philosophy that the marketplace is the 'test' of a firm's innovative activities, we define new product performance as the percentage of sales generated through new products targeted at new markets and such an approach is also consistent with the approach of Fitzgerald et al. (2008).

\section{The Top Management Team}

We focus on the top management team because these individuals have an important impact on organizational outcomes through the decisions they make (Thomas, Clark \& Gioia, 1993; Finkelstein \& Hambrick, 1996; Carpenter, Geletkanycz \& Sanders, 2004). The top team are viewed as strategic decision makers and the decisions they make are a result of the interactions of team members and the type and variety of cognitive perspectives represented in the team (Wiersema \& Bantel, 1992). The actions taken and decisions made by these teams can directly affect organizational innovation and new product performance (Bantel \& Jackson, 1989; Smith et al., 1994). Innovation requires a certain type of leadership. For example, Abetti (2000) argues that radical technological innovation requires a multifunctional leadership team open to debate. Ollila (2000) calls for more reflexive leadership and writers such as Rickards and Moger (2000) make a strong case for creative leadership. However, there is considerable evidence - both anecdotal and empirical - to suggest that TMTs do not always reach their full potential. It is therefore imperative to identify the factors that enhance or impede effective top team working and innovation/ new product performance.

\section{Task Reflexivity and New Product Performance}

West (1996, p. 559) defines task reflexivity as the 'extent to which team members collectively reflect upon the team's objectives, strategies and processes as well as their wider organizations and environments, and adapt them accordingly'. Reflexivity in an organizational setting involves individuals or teams reflecting upon their preferred work methods and modifying them where necessary according to the needs of the task or environment. Reflexivity is a multifaceted concept involving questioning, reviewing, evaluating, debating and adapting and, hence, is more than merely reflecting on what has already taken place. West (2002) describes a team demonstrating high reflexivity as one characterized by greater attention to detail, inclusiveness of potential problems, critical debate, long as well as short range planning and adaptation. These behaviours can create a 'conceptual readiness' for innovation (West, 2002) as the continuous monitoring and adaptation enable the team to develop new meaning and shared understanding (Hoegl \& Parboteeah, 2006) and are 
likely to lead to effective innovation implementation (Frese \& Zapf, 1994; Gollwitzer, 1996).

Because reflexivity has been found to be associated with outcomes such as innovative behaviour, it has generated a lot of interest recently in the organizational learning and innovation literature (Carter \& West, 1998; West, 2000). Carter and West (1998) found team reflexivity to be a predictor of senior manager's rating of programme effectiveness and creativity. Reflexivity has been found to be positively associated with team outcomes such as team innovation and innovative work behaviour (West \& Anderson, 1996; Carter \& West, 1998; De Dreu, 2002), team effectiveness (Tjosvold, 1990) and effective problem solving (Bottger \& Yetton, 1987). Teams with a high level of reflexivity and minority dissent were found to be more effective and innovative than teams that had low levels of reflexivity (De Dreu, 2002). Lee (2008) found task reflexivity within new product development teams positively influenced new product development performance. Although the majority of the research on reflexivity and innovation explores innovation at the team level (West, Borrill \& Unsworth, 1998; West, 2000), we suggest that reflexivity within the top team may have implications for firm level innovation and the resulting new product performance. Whether organizational innovation is successful or not depends finally on the marketplace. Thus, in the present study, we focus on new product performance as the percentage of revenues generated by new products to new customers during the preceding three years. Top management teams that engage in reflexive behaviours such as planning, debating, monitoring of external and internal environment, critical problem solving and adaptation are more likely to be able to adapt to new conditions, be proactive and bring about radical change (West et al., 2004; Hoegl \& Parboteeah, 2006).This is similar to what Sundbo (2003) refers to as 'strategic reflexivity', a concept he argues is core to the innovativeness of the firm and what Rickards and Moger (2000, 2006) refer to as creative leadership. While much of the creative leadership literature concentrates on the importance of leadership within the team, it is also necessary to have creative leadership at the top as this will cascade down throughout the organization.

Since the decisions and actions of top managers play a pivotal role in shaping organizational outcomes, we suggest that task reflexivity in top management teams should have a positive effect on new product performance because such teams continuously assess the current environment and adapt for the future. We therefore hypothesize the following:

\section{H1: TMT reflexivity will have a positive effect on new product performance.}

\section{TMT Knowledge Sharing and New Product Performance}

TMT knowledge sharing can be defined as the extent to which TMT members exchange and combine information and knowledge within their organization to make informed decisions about the course of action for the organization. Nahapiet and Ghoshal (1998) provide a simple but convincing model depicting learning and knowledge sharing as occurring primarily in two ways - through the combination and exchange of knowledge. Combination describes the process by which prior knowledge is combined to create new knowledge. This can happen in two ways, either by combining knowledge that was previously unconnected or by finding novel ways of combining knowledge that had been previously associated. The second mechanism identified by Nahapiet and Ghoshal (1998) is the exchange of knowledge. They note that the combination of knowledge often depends on the exchange of information, especially where resources are held by different parties. In order to gain access to the information, the transfer of information from one party to another is required. Knowledge sharing among TMT members can influence organizational outcomes (Dutton, Fahery \& Narayanan, 1983; Thomas, Clark \& Gioia, 1993), the level of risk taking, involvement and top team commitment to strategic issues (Kahneman \& Tversky, 2000) and decisions regarding innovation (Clark \& Smith, 2006).

Moran and Ghoshal (1996) suggest that in order to facilitate knowledge sharing the opportunity to combine/exchange information and the perceived value of the outcome must exist. Further, they suggest that different parties must exhibit motivation to combine and exchange information. Finally, Nahapiet and Ghoshal (1998) suggest that for knowledge sharing to take place the parties must be capable of doing so. That is, the combination and exchange of knowledge cannot take place unless parties are capable of doing so. This is similar to transactive memory systems or the team's collective capacity to learn and transfer knowledge: it is not enough for team members to have diverse and valuable knowledge as individuals - this knowledge must be shared and collectively embedded (Lewis, Lange \& Gillis, 2005). The role of knowledge sharing on innovation and competitive advantage has 
been emphasized by several researchers (e.g., Nonaka, 1994; Caloghirou, Kastelli \& Tsakanikas, 2004; Stata, 2004; Basadur \& Gelade, 2006). In light of the above, we propose that:

H2: TMT knowledge sharing will positively affect new product performance.

\section{TMT Composition, Knowledge Sharing and Reflexivity}

The literature on TMT rooted in the upperechelon theory (Hambrick \& Mason, 1984; Thomas, Clark \& Gioia, 1993; Finkelstein \& Hambrick, 1996; Carpenter, Geletkanycz \& Sanders, 2004) suggests that TMT dynamics and the effective functioning of the team can enhance creative problem solving within the team and enable executives to draw on their diverse experiences and knowledge to make high quality decisions (Nadler, 1996; Edmondson, Roberto \& Watkins, 2002). Specifically, TMT composition and trustworthiness may influence the TMT's knowledge sharing capabilities and task reflexivity. Both TMT composition and dispersion (age, education, tenure and functional background) may affect the TMT processes (e.g., Lyon \& Ferrier, 2002; Peterson et al., 2003; Camelo-Ordaz, Hernandez-Lara \& Valle-Cabrera, 2005) and thus indirectly affect innovation.

There is general agreement in the literature that the higher the level of education attained, the more receptive to creative solutions and innovation the person will be (Bantel \& Jackson, 1989; Thomas, Litschert \& Ramaswamy, 1991). Smith, Collins and Clark (2005) found education indirectly affected the number of new products and services through the firm's knowledge creation capacity and they argue the level of education can also be considered an indication of the 'knowledge stock' of the top management team. Daghfous (2004) argues that a prior knowledge base within the team is essential if valuable knowledge sharing is to take place. The level of education affects the ability to combine and create knowledge and the 'absorptive capacity' of the unit through the knowledge assimilation phase (Vinding, 2000). Therefore, employees with higher levels of education are better equipped to share and absorb new knowledge. Similarly, a higher stock of knowledge in the form of TMT's educational attainment may also enhance task reflexivity of the TMT. Task reflexivity involves the ability to critically evaluate and reflect upon past decisions and actions and to adapt accordingly. While there is little empirical data on the relationship between educational level and task reflexivity, there is sufficient theoretical evidence to suggest that higher educational attainment will be positively associated with task reflexivity behaviours such as critical debate and problem solving. Hence, we propose that:

\section{H3: TMT educational level will positively affect task reflexivity and knowledge sharing.}

Research on age diversity suggests that diversity in age within the TMT may have negative consequences for the organization. It can result in dysfunctional conflict, lack of consensus and ineffective communication as age diversity can deter the development of a shared language between individuals that results from similar background and experiences (Pfeffer, 1983; Zenger \& Lawrence, 1989). West, Patterson and Dawson (1999) found that the more teams differed in age, the lower the profitability of their company. Teams that do not possess a shared mental model of the task objectives find it difficult to communicate, collaborate and co-ordinate their strategies as a team. While there is little empirical data on direct relations between age diversity and knowledge sharing and task reflexivity, the majority of the diversity literature suggests relational diversity measures such as age can have negative impact on team outcomes. Hence, we propose that:

H4: TMT age diversity will negatively affect task reflexivity and knowledge sharing.

The relationship between functional diversity and knowledge sharing has been well documented in the knowledge management literature. Bunderson and Sutcliff (2002) suggest that functional diversity can have both positive and negative effects on information sharing depending on what measure of diversity is used. They found that functional diversity was positively associated with information sharing - but only when team members had broad experience in a range of functional areas. Functional diversity can increase the chance that new knowledge will be related to knowledge already existing in the organization/team, and therefore enhancing the assimilation of that new knowledge (Daghfous, 2004). It also provides different viewpoints and perspectives from which to process the knowledge-leading to the creation of new knowledge (Nonaka, 1994; Daghfous, 2004). The cognitive resource perspective argues that functional diversity leads to a diversity in knowledge bases and access to a variety of knowledge bases is needed in order to create and combine knowledge (Webber \& Donahue, 2001). Smith et al. (1994) found functional diversity was directly related to the firm's 
knowledge creation capacity and that in turn affected innovation. Jackson, in her review of the diversity literature, suggests that task diversity such as functional diversity may stimulate many opportunities for reflexivity, while this would be less likely in homogeneous groups (Jackson, 1992). Functional diversity may enhance debate and reflection around task-related information and Van Knippenberg and Schippers (2007) argue that divergent perspectives may encourage a team to reflect on its own functioning. In light of the above, we propose that:

H5: TMT functional diversity will positively affect task reflexivity and knowledge sharing.

Diversity in TMT tenure was found to decrease levels of cohesion and trust and lead to lower levels of group specific knowledge (Lawrence, 1997), group-level social and individual integration ( $\mathrm{O}^{\prime}$ Reilly, Caldwell \& Barnett, 1989). However, other researchers suggest that tenure diversity may lead to increased creativity and innovation (e.g., Katz, 1982; O'Reilly \& Flatt, 1989). There is evidence to suggest that tenure diversity reduces complacency and groupthink and enhances creativity and innovation (Katz, 1982; Bantel \& Jackson, 1989; O’Reilly \& Flatt, 1989). Tenure diversity can increase the motivation to debate and challenge the status quo (Michel \& Hambrick, 1992) and newcomers can create benefit for the team by adding fresh perspectives and objectivity. Diversity in tenure may also enhance the creation of new knowledge. By combining the experience and knowledge of the company that long tenured team members have with new knowledge and fresh insights that lesser tenured individuals may bring to the organization, new knowledge may emerge. We argue that diversity in TMT tenure will facilitate debate, reflexivity and knowledge sharing. In light of this, we propose that:

H6: TMT tenure diversity will positively affect task reflexivity and knowledge sharing.

\section{Trustworthiness}

We propose that trustworthiness within the TMT is an important variable in the innovative process (Mayer, Davis \& Schoorman, 1995). Three important attributes of trustworthiness are: ability, benevolence and integrity. Studies on trustworthiness (e.g., Ruppel \& Harrington, 2000; Clegg et al., 2002) provide support for the role of trustworthiness in influencing innovative behaviour and innovation. Trustworthiness can influence innovation in an indirect manner through the intervening processes of reflexivity and knowledge sharing. Prior studies (e.g., O'Reilly, Chatman \& Anderson, 1987; Schippers, Den Hartog \& Koopman, 2001) suggest that trustworthiness affects team's task reflexivity positively and may lead to increased dialogue and shared communication resulting in information and knowledge exchange among the members. Similarly, Madhavan and Grover (1998) argue that trustworthiness in teams is an important process variable for the creation of new knowledge. The role of trustworthiness among TMT members has some support from the studies of Simons and Peterson (2000) and Farrell et al. (2005) who reported that trustworthiness among TMT members mediated the relationship between TMT leadership and organizational knowledge sharing.

We suggest that perceptions of trustworthiness of other team members' competence and benevolence are important if individuals are going to engage in the sharing of valuable information or critically reflecting upon past decisions. Further, team reflexivity involves intense self-exploration both at a team and individual level and involves all team members (Hoegl \& Parboteeah, 2006). If individuals trust each other they are more likely to admit mistakes, question assumptions and engage in debate (Edmondson, 1999). It is therefore possible that trustworthiness among TMT members can reduce opportunistic, selfinterest seeking behaviours, reduce dysfunctional conflicts and promote sharing of knowledge and greater reflexivity (Ensley, Pearson \& Amason, 2002; Edmondson, 2004). Hence, we propose that:

H7: Trustworthiness among TMT members should positively influence TMT task reflexivity and knowledge sharing.

In the next section, we present the methodology used to test our model.

\section{Method}

The sample consisted of 39 small to medium domestic Irish software firms and is consistent with other similar studies involving TMTs (e.g., West \& Anderson, 1996). The focus of this study was small to medium Irish software companies. To be included in the study, firms needed to be in the software business, Irish owned and have at least 30 employees. Our pilot study suggested that TMTs, formal structures and processes were in place for firms with 30 or more employees. Of the 150 firms that met all the criteria, 39 firms agreed to participate resulting in a response rate of 
$26 \%$. However, this participation rate is good considering the demands placed on respondents, the senior level of respondents and the pace of change in the industry. The companies that agreed to participate did not differ significantly in terms of employee numbers from those not participating $\left(t_{140}=1.59, \mathrm{~ns}\right)$. It was not possible to obtain employee number information for ten of the non-responding firms. The number of members in the top team ranged between two and eight and the average team size in the sample was five. The average number of top team members who responded to the survey was three. The average age of team members was 35 with ages varying between 27 and 64 (mean $=39, \mathrm{SD}=10.81)$.

During a semi-structured interview with the CEOs averaging 50 minutes, each CEO identified his/her TMT members. Thus, in addition to the 39 CEOs, 160 TMT members completed the survey. We collected data on innovation from the CEO and the TMT members provided us with data on TMT composition, trustworthiness, reflexivity and knowledge sharing. A Likert scale was used for all items. Each scale ranges from $' 1=$ strongly disagree' to ' $5=$ strongly agree'.

\section{Measures}

\section{New Product Performance}

Consistent with the literature on innovation and new product performance (Damanpour, 1991; Fitzgerald et al., 2008), we operationalize new product performance as the percentage of revenue generated by new products targeted at new markets over the last three years.

\section{TMT Composition}

The demographic measures used include both demographic dispersion measures (age diversity, tenure diversity and functional diversity) and direct measures (education level). To measure functional diversity, respondents were asked what their functional background was. Functional diversity was calculated using Blau's (1977) heterogeneity index. A higher score on this indicates a higher level of functional diversity and a low score represents a lower level of functional diversity. Age diversity was calculated as the coefficient of variation in age of team members as a direct method for obtaining a scale invariant measure of dispersion (Allison, 1978; Bantel \& Jackson, 1989; Knight et al., 1999). A score of zero indicates perfect homogeneity along the given dimension and a higher score indicates a higher level of diversity. The questionnaire asked respondents to report how long they had been in their current position with the team. Tenure diversity was then computed as the coefficient of variation (the standard deviation divided by the mean) of team tenure among top team members.

\section{Education Level}

Prior research (e.g., Kimberly \& Evanisko, 1981; Smith, Collins \& Clark, 2005) suggests that that average education level can act as a proxy for the creative ability and knowledge stock within the top team and therefore suggest an association between level of education attained and innovation. Consistent with this approach, education was computed as mean of the number of years of post-secondary education for each top management team.

\section{TMT Trustworthiness}

In this study, we used the measure of trustworthiness of Mayer and Davis (1999). We used 12 items to measure trustworthiness. An exploratory factor analysis indicated two factors with two items not clearly loading on any of the two factors. Further, the rwg(j) statistic for the two scales ranged from 0.89 to 0.91 . The intra-class correlation coefficient value of 0.87 for the trustworthiness scale suggested that it would be appropriate to aggregate the scale at the firm level. Hence, consistent with the suggestion of James, Demaree and Wolf (1993), we aggregated the two factors and formed a single index of trustworthiness with an internal consistency reliability of 0.81 . Responses were gathered on a five-point Likert scale, which ranged from $1=$ strongly disagree to $5=$ strongly agree. The data was coded such that a higher score indicated a higher level trustworthiness.

\section{Knowledge Sharing}

We measured knowledge sharing using the measure developed by Smith et al. (2005). The 17 items measuring knowledge sharing loaded on two factors with factor loadings in excess of 0.50 with five items not clearly loading on any of the two factors. Six items (e.g., 'Employees find exchange/combination of ideas with members of this firm one of the most motivating parts of their jobs' and 'Employees believe that by combining and exchanging information they create value for the organization') measuring the motivation to share information loaded on one factor (Cronbach's alpha $=0.84$ ). Another six items (e.g., 'Employees meet frequently to discuss ideas and new developments', 'Employees are capable of sharing expertise to bring new projects to fruition' and 'Employees are proficient at combining and exchanging ideas to solve problems/create 
opportunities') loaded on a second factor (Cronbach's alpha $=0.84$ ). The intra-class correlation coefficient value of 0.83 for the knowledge sharing ability and 0.88 for the knowledge sharing motivation indicated that it would be appropriate to aggregate the scale at the firm level and, hence, we aggregated the scale to the firm level with a higher score indicating a higher level of knowledge sharing ability and knowledge sharing motivation.

\section{Reflexivity}

The reflexivity items in the questionnaire were derived from Carter and West's (1998) model of reflexivity. Sample questions in the survey included: 'We regularly discuss whether the TMT is working effectively together', 'The TMG often reviews its objectives' and 'In this TMG we modify objectives in light of changing circumstances'. The intra-class correlation coefficient value of 0.91 indicated that it would be appropriate to aggregate the scale at the firm level. The data from TMT questionnaires was combined in order to derive a team level measure of reflexivity (Cronbach's alpha $=0.80$ ).

\section{Data Analyses Strategy}

In order to determine whether it was appropriate to aggregate individual TMT responses to the firm level, we conducted $\operatorname{rwg}(j)$ and intraclass correlation analyses. The rwg statistic ranged from 0.80 to 0.94 and intra-class correlations ranged from 0.83 to 0.91 . Hence, the decision to aggregate was made. We used the methodology suggested by Pedhazur (1982) to derive the path coefficients with the TMT size as the control variable. The path coefficient from a predictor to the dependent variable is the standardized regression coefficient for the predictor controlling for all other predictors in the equation. We used one tailed $t$-tests to test for the significance of the hypothesized path coefficients. In order to test for the significance of the overall model, we conducted the log likelihood test suggested by Pedhazur (1982, p. $619)$ that tested the over-identified model with the constrained paths with the just-identified model with all possible paths. The null hypothesis tested was that the over-identified model fits the data as well as the just-identified model. When the resultant Chi-square statistic for the over-identified model is less than the critical Chi-square with the number of constrained paths as the degrees of freedom $(p>0.05)$, the null hypothesis is retained suggesting that the over-identified model adequately fits the data as well as the just-identified model. Since the Chi-square statistic is greatly influenced by the sample size and has a tendency to reject the null-hypothesis even when the model fits the data well (Joreskog \& Sorbom, 2001), we also examined the measure of goodness of fit $(Q)$, suggested by Pedhazur (1982) for overidentified models. This measure of goodness of fit can range from 0 to 1 with a value of 1 indicating a perfect fit and a value of 0 indicating no fit at all.

\section{Results}

Table 1 shows the means, standard deviations and inter-correlation matrix of the variables used in this study. Figure 2 presents the model that emerged indicating the path coefficients with the associated significance levels. We obtained a goodness of fit index ( $Q$ coefficient) of 0.86 which indicated that the over-identified model obtained in our study fits the data as well as the just-identified model and is consistent with the results obtained by Fitzgerald et al. (2008). Further, the Chi-square statistics of 4.69 with 26 degrees of freedom (number of constraints imposed on the data) obtained in our study fell between the $\alpha=0.98$ and $\alpha=99$ range, thus failing to reject the null hypothesis that the over identified model fits the data as well as the just identified model.

Hypothesis 1 indicated that reflexivity would positively influence new product performance which was supported as the path coefficient from reflexivity to new product performance $(\beta=0.32, p<0.05)$ was positive and in the predicted direction. In addition, the control variable of TMT size $(\beta=-0.25$, $p<0.05)$ influenced innovation negatively. Hypothesis 2 was also partially supported as the path coefficient $(\beta=0.25, p<0.05)$ from knowledge sharing motivation to innovation was positive and significant; however, knowledge sharing ability did not affect innovation after controlling for motivation.

Hypothesis 3 indicated that educational level of TMT would positively influence reflexivity and knowledge sharing ability. This hypothesis was not supported as direct paths from educational level to reflexivity and knowledge sharing ability were not significant. However, educational level indirectly influenced these two variables through the variable of trustworthiness as the path coefficients from educational level to trustworthiness $(\beta=0.32, p<0.05)$ was significant and the trustworthiness to reflexivity $(\beta=0.38$, $p<0.01)$ and trustworthiness to knowledge sharing ability $(\beta=0.46, p<0.001)$ relationships were also significant.

Hypotheses 4 and 5 suggested that age diversity would negatively and functional diversity would positively affect reflexivity and knowledge sharing, respectively. While 


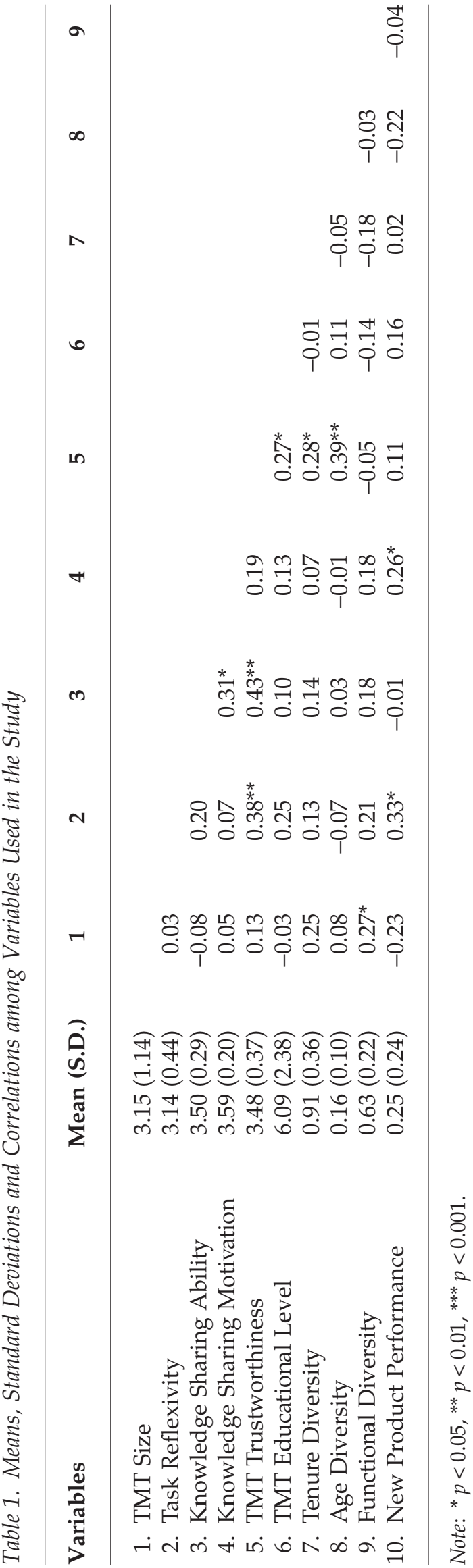

H5 did not receive support, $\mathrm{H} 4$ was supported partially. In this study, age diversity negatively influenced reflexivity and knowledge sharing through the intervening variable of trustworthiness $(\beta=-0.41, p<0.01)$. Thus trustworthiness seems to be a critical issue in understanding the relationships between diversity in TMT and the process variables of reflexivity and knowledge sharing. However, contrary to our hypothesis, age diversity positively $\left(\beta=0.23^{*}, \quad p<0.05\right)$ influenced knowledge sharing ability. Perhaps age diversity in TMT facilitates sharing of organizational specific knowledge brought in by older employees and the new knowledge brought in by younger TMT members.

Hypothesis 6 suggested that tenure diversity should positively impact reflexivity and knowledge sharing. This hypothesis was not supported as the direct path coefficients from this diversity measure to reflexivity and knowledge sharing motivation were not significant. However, results indicated an indirect relationship as the path coefficient from tenure diversity to TMT trustworthiness $(\beta=0.26, p<0.05)$ was positive and significant.

Finally, H7 suggested that trustworthiness would positively affect reflexivity and knowledge sharing. As indicated earlier, this hypothesis was supported as the path coefficients were statistically significant.

\section{Discussion}

The core objective of this study was to investigate the determinants of new product performance in knowledge intensive companies and, from this, to build a more informed and evidence-based picture of the innovative process. In doing this, the role of top management team composition, trust and group processes in fostering innovation was investigated.

Exploring relationships between TMT diversity and organizational innovation in isolation is unlikely to yield a definitive understanding of the role of diversity. However, studying TMT diversity in conjunction with other team processes can give rise to a more robust understanding of the role of TMT. First, we would like to point out that lack of direct effects of diversity measures on the two TMT processes - knowledge sharing and reflexivity - may initially give the impression that diversity does not matter. However, the fact that diversity measures of age and education influence trustworthiness that in turn influence these two process variables seems to suggest the crucial role of trustworthiness to the field of diversity literature. Because differ- 


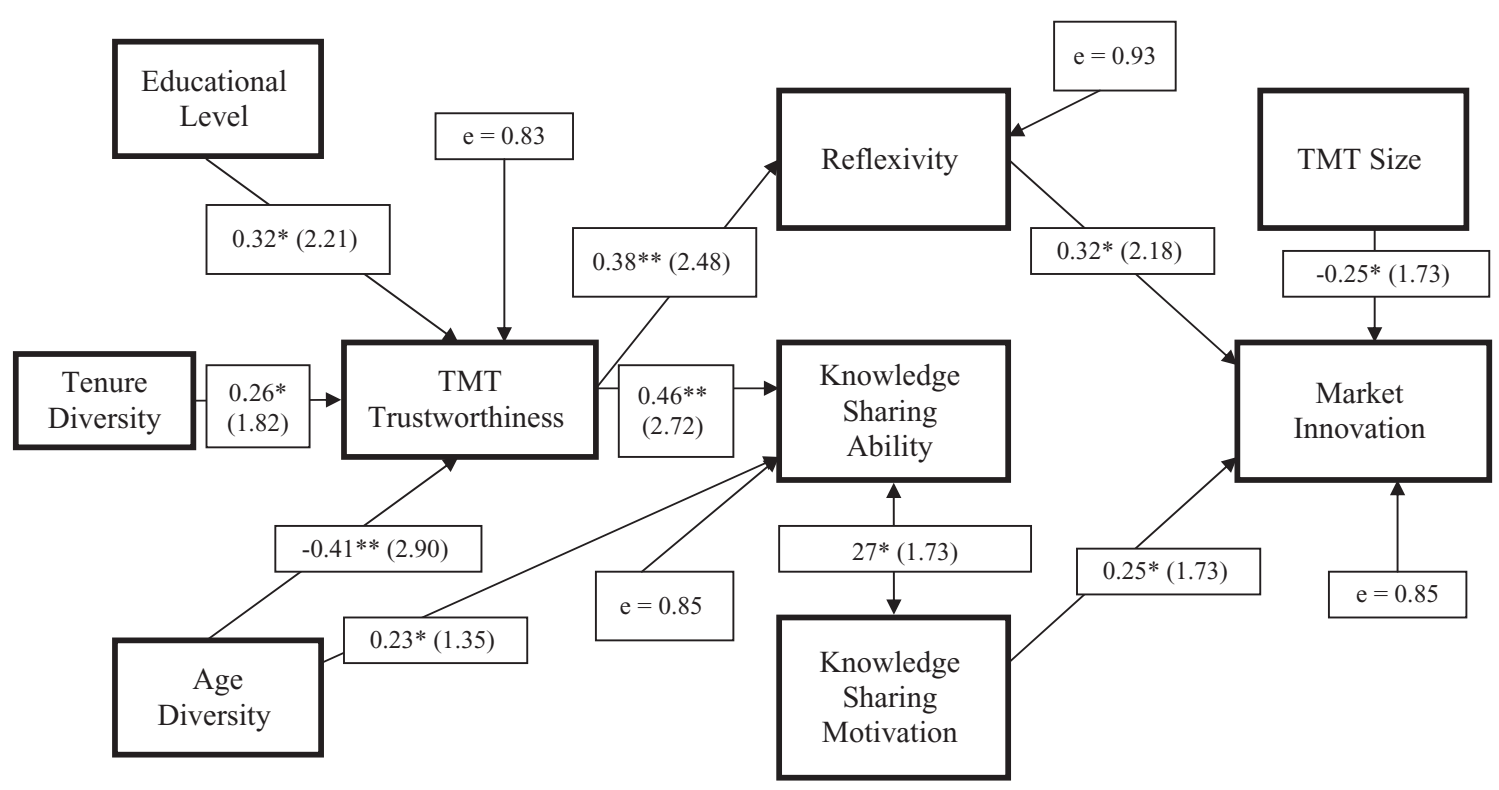

Figure 2. Top Management Team (TMT) Knowledge Sharing and New Product Performance: Emergent Model

ence based on age is often value laden, it may be that this type of diversity is more likely to lead to lack of trustworthiness. This is not to suggest that age diversity within teams should be avoided. Age diversity and the different perspectives that come with it can also facilitate group creativity and debate (Bantel \& Jackson, 1989); however, this study suggests that it is more likely to be associated with low levels of trustworthiness within the team and any associated negative outcomes arising out of it. It is therefore necessary that teams are cognizant of such negative outcomes and are trained to work effectively together to achieve shared understanding (West, 2000).

We found a positive relationship between TMT educational level and trustworthiness within the TMT. Thus it appears that the more educated the TMT members, the more likely the trustworthiness among the TMT perhaps due to a lack of insecure feelings and/or reliance on the competence of others as well as oneself. Further, trustworthiness among TMT members also resulted in a higher level of knowledge sharing and reflexivity. Where there are high levels of trust, there is more likely to be honest discussion of problems, issues and reflection on the task at hand. Edmondson (2004) found that psychological safety (a concept incorporating trust) within teams increased the potential for review and reflecting upon mistakes. This study suggests that the more a team trust in each other's competence and goodwill, the more likely it is they will admit to and discuss mistakes and question why projects failed and try to rectify those mistakes. Such a reflection and sharing of ideas seem to have a positive impact on the organization in terms of increased share of revenues coming from new products.

Reflexivity has been found to be positively associated with team outcomes such as team innovation (West \& Anderson, 1996), team effectiveness (Tjosvold, 1990) and effective problem solving (Bottger \& Yetton, 1987). Our study is one of the first studies to explore the relationship between reflexivity and organizational outcomes and these results indicate that how the TMT approach the tasks that face them on a daily basis is directly associated with innovation. The literature on reflexivity suggests that this activity is particularly important for groups working on challenging tasks and operating in complex environments (Tjosvold, Tang \& West, 2004). This seems to be the case for the TMTs in our sample of firms in the software industry that often face an uncertain and complex environment. We also predicted a positive association between the TMT knowledge sharing and innovation and looked at two important dimensions of knowledge sharing: the ability to share knowledge and the motivation to share knowledge (Nahapiet \& Ghoshal, 1998). Only one of these dimensions is directly associated with innovation in this study - the motivation to share knowledge. The ability to share knowledge is not linked to innovation suggesting that having access to knowledge sharing opportunities and believing that others are capable of sharing knowledge is not enough to generate innovation. In order to be motivated to ex- 
change knowledge, individuals need to expect an outcome that will be of personal value to them even if they are not certain of what that newly created value will be (Nahapiet \& Ghoshal, 1998). This research indicates that TMT knowledge sharing predicts innovation when employees can experience the value in the learning activity.

Our study focuses on software industry companies that are Irish owned. In doing so, we are somewhat controlling for the influence of cultural differences in the management of the firm. Foreign owned firms may not only face uncertainty and complexity in their industry environment but also challenges in terms of management and group dynamics of foreign owners versus local managers arising out of cultural differences. It would be worthwhile to extend our study in the future to firms with foreign ownership and examine the role of trustworthiness, reflexivity and knowledge sharing among TMT members as cultural differences may also play a big role in these dynamics.

\section{Limitations and Conclusion}

There are some limitations to this study. The sample in this study consisted of only 39 top management teams. Given the nature of our study with its focus on TMTs, the sample may be considered acceptable (for similar sample size, see West and Anderson (1996) whose study on top management teams consisted of 27 teams). A second limitation concerns the cross-sectional nature of the research design. Nevertheless, our use of the data sources from different respondents within the company may partially alleviate the problems associated with cross-sectional studies. Finally, we used percentage of new products going to new markets as a measure of new product performance. In doing so, we focused on the direct outcome of innovation. While marketplace is the final place where a firm's innovativeness is put to the test, innovation is also a process. Future studies may perhaps look at other measures of innovations such as patents, number of new products or process improvements made and the resultant cost savings, to name a few. Kanter (1983) argues that an organization's top team and the 'right' team environment are important predictors of the innovative process. While the exploration of the role of top team and the 'right' environment in determining innovation is nothing new, most studies focus on one or the other. To a limited extent, our study contributes to the literature by integrating both perspectives.

\section{References}

Abetti, P. (2000) Critical Success Factors for Radical Technological Innovation: A Five Case Study. Creativity and Innovation Management, 9, 208-21.

Allison, P.D. (1978) Measures of Inequality. American Sociological Review, 43, 865-80.

Anderson, N.R., Hardy, G. and West, M.A. (1990) Innovative Teams at Work. Personnel Management, $22(9), 48-53$.

Baldwin, J.R. (1995) Innovation: The Key to Success in Small Firms. Unpublished manuscript, Yale School of Management's Management Research Network, 1-25.

Bantel, K.A. and Jackson, S.E. (1989) Top Management and Innovations in Banking: Does the Composition of the Top Team Make a Difference? Strategic Management Journal, 10, 107-24.

Basadur, M. and Gelade, G.A. (2006) The Role of Knowledge Management in the Innovation Process. Creativity and Innovation Management, 15, 45-62.

Bergstein, H. and Estelami, H. (2002) Survey of Emerging Technologies for Pricing New-to-theWorld Products. Journal of Product and Brand Management, 11, 303-19.

Black, S.E. and Lynch, L.M. (2004) What is Driving the New Economy? The Benefits of Workplace Innovation. Economic Journal, 114, F97-F116.

Blau, P.M. (1977) Inequality and Heterogeneity. Free Press, New York.

Bottger, P.C. and Yetton, P.W. (1987) Improving Team Performance by Training in Individual Problem Solving. Journal of Applied Psychology, 72, 651-7.

Bunderson, J.S. and Sutcliff, K.M. (2002) Comparing Alternative Conceptualisations of Functional Diversity in Management Teams: Process and Performance Effects. Academy of Management Journal, 45, 875-93.

Caloghirou, Y., Kastelli, I. and Tsakanikas, A. (2004) Internal Capabilities and External Knowledge Sources: Complements or Substitutes for Innovative Performance? Technovation, 1, 29-39.

Camelo-Ordaz, C., Hernandez-Lara, A.B. and Valle-Cabrera, R. (2005) The Relationship between Top Management Teams and Innovative Capacity in Companies. Journal of Management Development, 24, 683-705.

Carpenter, M.A., Geletkanycz, M.A. and Sanders, W.G. (2004) Upper Echelons Research Revisited: Antecedents, Elements, and Consequences of Top Management Team Composition. Journal of Management, 30, 749-78.

Carter, S.S. and West, M.A. (1998) Reflexivity, Effectiveness and Mental Health in BBC Production Teams. Small Group Research, 29, 583-601.

Clark, K.D. and Smith, K.G. (2006) Top Management Team Social Networks and Organizational Innovation: An Information Theory Explanation of TMT Value Creation, Working Paper, Robert Smith School of Business, Maryland.

Clegg, C., Unsworth, K., Epitropaki, O. and Parker, G. (2002) Implicating trust in the innovation process. Journal of Occupational and Organizational Psychology, 75, 409-22.

Daghfous, A. (2004) Absorptive Capacity and the Implementation of Knowledge-Intensive 
Practices. SAM Advanced Management Journal, Spring, 21-27.

Damanpour, F. (1991) Organizational Innovation: A Meta Analysis of Effects of Determinants and Moderators. Academy of Management Journal, 34, 555-90.

De Dreu, C.K. (2002) Team Innovation and Team Effectiveness: The Importance of Minority Dissent and Reflexivity. European Journal of Work and Organisational Psychology, 11, 285-98.

De Dreu, C.K. (2006) When Too Little or Too Much Hurts: Evidence for a Curvilinear Relationship between Conflict and Innovation in Teams. Journal of Management, 32, 83-107.

Dutton, J.E., Fahery, L. and Narayanan, V.K. (1983) Toward Understanding Strategic Issue Diagnosis. Strategic Management Journal, 4, 307-23.

Edmondson, A.C. (1999) Psychological Safety and Learning Behaviour in Work Teams. Administrative Science Quarterly, 44, 350-84.

Edmondson, A.C. (2004) Learning from Mistakes is Easier Said than Done: Group and Organisational Influences on the Detection and Correction of Human Error. Journal of Applied Behavioural Science, 40, 66-90.

Edmondson, A.C., Roberto, M. and Watkins, M. (2002) A Dynamic Model of Top Management Team Effects: Managing Unstructured Task Teams. Leadership Quarterly, 14, 297-325.

Ensley, M.D., Pearson, A.W. and Amason, A.C. (2002) Understanding the Dynamics of New Venture Top Management Teams: Cohesion, Conflict and New Venture Performance. Journal of Business Venturing, 17, 365-86.

Farrell, J., Flood, P., MacCurtain, S., Hannigan, A., Dawson, J. and West, M. (2005) CEO Leadership, Top Management Team Trust and the Combination and Exchange of Information. Irish Journal of Management, 26, 22-40.

Finkelstein, S. and Hambrick, D. (1996) Strategic Leadership - Top Executives and their Effects on Organizations. West Publishing Company, New York.

Fitzgerald, C.A., Flood, P.C., O'Regan, P. and Ramamoorthy, N. (2008) Governance Structures and Innovation in the Irish Software Industry, Journal of High Technology Management Research, $19,36-44$.

Frese, M. and Zapf, D. (1994) Action as the Core of Work Psychology: A German Approach. In Triandis, H.C., Dunnette, M.D. and Hough, L.M. (eds.), Handbook of Industrial and Organizational Psychology. Consulting Psychologists Press, Palo Alto, CA, pp. 271-340.

Gollwitzer, P.M. (1996) The Volitional Benefits of Planning. In Gollwitzer, P.M. and Bargh, J.A. (eds.), The Psychology of Action: Linking Cognition and Motivation to Behaviour. Guilford Press, New York, pp. 287-312.

Hage, J. and Dewar, R. (1973) Elite Values versus Organisational Structures in Predicting Innovation. Administrative Science Quarterly, 18, 27991.

Hambrick, D. and Mason, P.A. (1984) Upper Echelons: The Organisation as a Reflection of its Top Managers. Academy of Management Review, 9, 195206.
Hoegl, M. and Parboteeah, K.P. (2006) Team Reflexivity in Innovative Projects. $R$ and $D$ Management, 36, 113-25.

Jackson, S.E. (1992) Consequence of Group Composition for the Interpersonal Dynamics of Strategic Issue Processing. In Shrivastava, P., Huff, A. and Dutton, J. (eds.), Advances in Strategic Management. JAI Press, Greenwich, CT, pp. 34582.

James, L., Demaree, R. and Wolf, G. (1993) An Assessment of Within Group Inter-Rater Agreement. Journal of Applied Psychology, 78, 30610.

Joreskog, K. and Sorbom, D. (2001) LISREL 8.50. Lincolnwood, IL.

Kahneman, D. and Tversky, A. (2000) Choices, Values and Frames. Sage, New York.

Kanter, R.M. (1983) The Change Masters: Innovation for Productivity in the American Corporation. Simon and Schuster, New York.

Katz, R. (1982) The Effects of Group Longevity of Project Commitment and Performance. Administrative Science Quarterly, 27, 81-104.

Kimberly, J. (1981) Managerial Innovation. In Nystrom, P.C. and Starbuck, W.H. (eds.), Handbook of Organisational Design. Oxford University Press, New York, pp. 84-104.

Kimberly, J. and Evanisko, M.J. (1981) Organisational Innovation: The Influence of Individual, Organisational, and Contextual Factors on Hospital Adoption of Technological and Administrative Innovations. Academy of Management Journal, 24, 689-713.

Knight, D., Pearce, C.L., Smith, G., Olian, J.D., Sims, H.P., Smith, K.A. and Flood, P. (1999) Top Management Team Diversity, Group Process and Strategic Consensus. Strategic Management Journal, 20, 445-65.

Lawrence, B.S. (1997) The Black Box of Organizational Demography. Organization Science: A Journal of the Institute of Management Sciences, 8, $1-22$.

Lee, L.T. (2008) The Effects of Team Reflexivity and Innovativeness on New Product Development Performance. Industrial Management and Data Systems, 108, 548-69.

Lewis, K., Lange, D. and Gillis, L. (2005) Transactive Memory System, Learning and Learning Transfer. Organization Science, 16, 581-98.

Lyon, D.W. and Ferrier, W.J. (2002) Enhancing Performance with Product-Market Innovation: The Influence of the Top Management Team. Journal of Managerial Issues, 14, 452-70.

Madhavan, R. and Grover, R. (1998) From Embedded Knowledge to Embodied Knowledge: New Product Development as Knowledge Management. Journal of Marketing, 62, 1-12.

Marks, M.A., Mathieu, J.E. and Zaccaro, S.J. (2001) A Temporally Based Framework and Taxonomy of Team Processes. Academy of Management Review, 26, 356-76.

Mascitelli, R. (2000) From Experience: Harnessing Tacit Knowledge to Achieve Breakthrough Innovation. Journal of Product Innovation Management, 17, 179-93.

Mayer, R.C. and Davis, J.H. (1999) The Effect of the Performance Appraisal System on Trust for Man- 
agement: A Field Quasi-Experiment, Journal of Applied Psychology, 84, 123-36.

Mayer, R.C., Davis, J.H. and Schoorman, F.D. (1995) An Integrative Model of Organisational Trust. Academy of Management Review, 20, 709-34.

Michel, J.C. and Hambrick, D. (1992) Diversification Posture and the Characteristics of the Top Management Team. Academy of Management Journal, 35, 9-37.

Moran, P. and Ghoshal, S. (1996) Value Creation by Firms. In Keys, J.B. and Dosier, L.N. (eds.) Academy of Management Best Paper Proceedings.

Nadler, D.A. (1996) Managing the Team at the Top. Strategy and Business, 2, 42-51.

Nahapiet, J. and Ghoshal, S. (1998) Social Capital, Intellectual Capital and the Organisational Advantage. Academy of Management Review, 23, 242-66.

Nonaka, I. (1994) A Dynamic Theory of Organizational Knowledge Creation. Organization Science, 5, 14-37.

Nonaka, I. (1999) The Dynamics of Knowledge Creation. In Ruggles, R. and Holtshouse, D. (eds.), The Knowledge Advantage: An Anthology. Capstone, Dover, NH, pp. 63-88.

Nonaka, I. and Takeuchi, H. (1995) The KnowledgeCreating Company. Oxford University Press, New York.

Ollila, S. (2000) Creativity and Innovativeness through Reflective Project Ladership. Creativity and Innovation Management, 9, 195-200.

O'Reilly, C.A. and Flatt, S.F. (1989) Executive Team Demography, Organisational Innovation and Team Performance. Paper presented at the Academy of Management Conference, Washington, DC.

O'Reilly, C.A., Chatman, J. and Anderson, J.C. (1987) Message Flow and Decision Making. In Jablin, F.M., Putman, L.L., Roberts, K.H. and Porter, L.W. (eds.), Handbook of Organisational Communication: An Interdisciplinary Perspective. Sage, Newbury Park, CA, pp. 600-23.

O'Reilly, C.A., Caldwell, D.F. and Barnett, W.P. (1989) Work Group Demography, Social Integration, and Turnover. Administrative Science Quarterly, 34, 21-37.

Pedhazur, E.J. (1982) Multiple Regression in Behavioural Research, 2nd edn. Harcourt Brace Jovanovich, Forth Worth, TX.

Peterson, R.S., Smith, D.B., Martorana, P.V. and Owens, P.D. (2003) The Impact of Chief Executive Officer Personality on Top Management Team Dynamics: One Mechanism by which Leadership Affects Organizational Performance. Journal of Applied Psychology, 88, 795-809.

Pfeffer, J. (1983) Organisational Demography. In Cummings, L.L. and Staw, B.M. (eds.) Research in Organizational Behavior, 5. JAI Press, Greenwich, CT, pp. 299-357.

Prajogo, D.I. and Ahmed, P.K. (2007) The Relationships between Quality, Innovation and Business Performance: An Empirical Study. International Journal of Business Performance Management, 9, 380-405.

Rickards, T. and Moger, S. (2000) Creative Leadership Processes in Project Team Development: An Alternative to Tuckman's Stage Model. British Journal of Management, 11, 273-83.
Rickards, T. and Moger, S. (2006) Creative Leaders: A Decade of Contributions from Creativity and Innovation Management Journal. Creativity and Innovation Management, 15, 4-18.

Ruppel, C.P. and Harrington, S.J. (2000) The Relationship of Communication, Ethical Work Climate and Trust to Commitment and Innovation. Journal of Business Ethics, 25, 313-28.

Schippers, M.C., Den Hartog, D.N. and Koopman, P.L. (2001) Reflexivity in Teams: The Relation with Trust, Group Potency, Team Leadership, and Performance in Work Teams. Paper presented at the Academy of Management, Washington, DC.

Schulz, M. (2001) The Uncertain Relevance of Newness: Organisational Learning and Knowledge Flows. Academy of Management Journal, 44, 661-81.

Simons, T.L. and Peterson, R.S. (2000) Task Conflict and Relationship Conflict in Top Management Teams: The Pivotal Role of Intra-Group Trust. Journal of Applied Psychology, 85, 102-11.

Smith, K.G., Olian, J., Sims, H.P., Scully, J., Smith, K.A. and O'Bannon, D. (1994) Top Management Team Demography and Process: The Role of Social Integration and Communication. Administrative Science Quarterly, 39, 412-38.

Smith, K., Collins, C. and Clark, K.D. (2005) Existing Knowledge, Knowledge Creation Capability, and the Rate of New Product Introduction in High-Technology Firms. Academy of Management Journal, 48, 346-57.

Song, X.M. and Dyer, B. (1998) Innovation Strategy and Sanctioned Conflict: A New Edge in Innovation. Journal of Product Innovation Management, 15, 505-20.

Spencer, J. (2003) Firms' Knowledge Sharing Strategies in the Global Innovation System: Empirical Evidence from the Flat Panel Display Industry. Strategic Management Journal, 24, 217-33.

Stata, R. (2004) New Ways to Evaluate Innovative Ventures. MIT Sloan Management Review, 45, 96.

Sundbo, J. (2003) The International Handbook of Innovation. Elsevier, Amsterdam.

Thomas, A., Litschert, R.J. and Ramaswamy, K. (1991) The Performance Impact of StrategyManager Co-Alignment: An Empirical Investigation. Strategic Management Journal, 12, 509-22.

Thomas, J.B., Clark, S.M. and Gioia, D. (1993) Strategy, Sense Making and Organizational Performance: Linkages among Scanning, Interpretation, Action and Outcomes. Academy of Management Journal, 36, 239-70.

Tidd, J. (2001) Innovation Management in Context: Environment, Organization and Performance. International Journal of Management Reviews, 3, 169-83.

Tidd, J., Bessant, J. and Pavitt, K. (2005) Managing Innovation: Integrating Technological, Managerial and Organizational Change. McGraw-Hill, New York.

Tjosvold, D. (1990) Making Technological Innovation Work: Collaboration to Solve Problems. Human Relations, 43, 1117-31.

Tjosvold, D., Tang, M. and West, M.A. (2004) Reflexivity for Team Innovation in China: The Contribution of Goal Interdependence. Group and Organization Management, 29, 540-59. 
Van Knippenberg, D. and Schippers, M. (2007) Work Group Diversity. Annual Review of Psychology, 58, 515-41.

Vinding, A.L. (2000) Absorptive Capacity and Innovative Performance: A Human Capital Approach. Department of Business Studies - DRUID/IKE Group, Aalborg Univeristy, Denmark.

Webber, S.S. and Donahue, L.M. (2001) Impact of Highly and Less Job Related Diversity on Work Group Cohesion and Performance: A Meta Analysis. Journal of Management, 27, 141-62.

West, M.A. (1996) Reflexivity and Work Group Effectiveness: A Conceptual Integration. In West, M.A. (ed.), Handbook of Work Group Psychology. Wiley, London, pp. 555-79.

West, M.A. (2000) Reflexivity, Revolution and Innovation in Work Teams. In Beyerlein, M.M., Johnson, D.A. and Beyerlein, S.T. (eds.), Advances in the Interdisciplinary Study of Work Teams: Product Development Team. JAI Press, Stamford, CT, pp. 1-29.

West, M.A. (2002) Sparkling Fountains or Stagnant Ponds: An Integrative Model of Creativity and Innovation Implementation in Work Groups. Applied Psychology: An International Review, 51, 355-87.

West, M.A. and Anderson, N.R. (1996) Innovation in Top Management Teams. Journal of Applied Psychology, 81, 680-94.

West, M.A., Borrill, C.S. and Unsworth, K.L. (1998) Team Effectiveness in Organizations. In Cooper, C.L. and Robertson I.T. (eds.), International Review of Industrial and Organizational Psychology, Vol. 13. John Wiley, New York, pp. 1-48.

West, M.A., Patterson, M.G. and Dawson, J. (1999) A Path to Profit? Teamwork at the Top. Centre Piece: the Magazine of Economic Performance, 4, 711.

West, M.A., Hirst, G., Richter, A. and Shipton, H. (2004) Twelve Steps to Heaven: Successfully Managing Change through Developing Innovative Teams. European Journal of Work and Organizational Psychology, 13, 269-99.

Wiersema, M.F. and Bantel, K.A. (1992) Top Management Team Demography and Corporate Change. Academy of Management Journal, 35, 91-121.

Zenger, T.R. and Lawrence, B.S. (1989) Organisational Demography: The Different Effects of Age and Tenure Distributions on Technical Communication. Academy of Management Journal, 32, 35376.

Sarah MacCurtain (sarah.maccurtain@ul.ie) is Lecturer in Organizational Behavior at the University of Limerick, Ireland. Dr MacCurtain is Co-Director of the Strategic Healthcare Management Research Group. She received her PhD from Aston Business School in 2005. Her continuing research interests include top management teams, trust and organizational performance, bullying, employee stress and well-being, organizational climate and innovation.
Patrick C. Flood (patrick.flood@dcu.ie) is Professor of Organizational Behaviour, Head of the HRM Group and a Deputy Director of the Leadership, Innovation and Knowledge (LInK) research centre at Dublin City University. A former Fulbright scholar, Professor Flood has held faculty and visiting appointments at the Australian Graduate School of Management, London School of Economics, London Business School, University of Limerick and the University of Maryland. Patrick's research interests include CEO leadership and top team effectiveness; HRM and organizational performance; management practices and professional service firms performance.

Dr Nagarajan Ramamoorthy received his $\mathrm{PhD}$ in Business and Management from the Robert H. Smith School of Business, University of Maryland at College Park. He is a recipient of Fulbright scholarship to Sofia, Bulgaria. His research interests are in the areas of international management, comparative management and strategic human resource management. His work has appeared in several international journals such as Human Relations, British Journal of Management, International Journal of Human Resource Management, Journal of International Management, among others. He has also presented his work in several leading national and international conferences.

Michael A. West (m.a.west@aston.ac.uk) is Professor and the Executive Dean of Aston Business School, Aston University, Birmingham. Professor West is a Fellow of the British Psychological Society, the American Psychological Association (APA), the APA Society for Industrial/organizational Psychology, The Royal Society for the Encouragement of Arts, Manufactures and Commerce, the International Association of Applied Psychologists, The Higher Education Academy, the British Academy of Management and a Chartered Fellow of the Chartered Institute of Personnel and Development. His areas of research interest are team and organizational innovation and effectiveness, particularly in relation to the organization of health services. He lectures widely both nationally and internationally about the results of his research and his ideas for developing effective and innovative organizations.

Jeremy F. Dawson (j.f.dawson@aston. ac.uk) is RCUK Research Fellow in the Work \& Organisational Psychology Group at Aston Business School, Aston University, Birmingham. His research interests include: measurement of organizational performance in healthcare, treatment of incomplete data in teams research, measurement of diversity in small groups, the effects of aggregation on statistical inference and probing moderated multiple regression (MMR). 